\title{
Akurasi Awal Waktu Zuhur Perspektif Hisab dan Rukyat
}

\author{
Lutfi Nur Fadhilah ${ }^{1}$ \\ S2 Ilmu Falak UIN Walisongo Semarang \\ 1email: lutfinurfadhilah@gmail.com
}

\begin{abstract}
This study discusses Zuhur time. It is necessary to practice between the phenomenon of the sun's position on the earth with the initial criteria based on hisab. This study is about Zuhur time because the four prayer times besides zuhur is based on the time of zuhur prayer.This study is field research. That ihtiyath Zuhur time ranges from 1 to 4 minutes between hisab and azan around the observation site. The zuhur hisab is relevant with the rule that zuhur time starts from the sun zawal, or increases the length of the shadow after the culmination formed by gnomon.
\end{abstract}

Keywords: Hisab, Observation, Zuhur, Ihtiyath.

\begin{tabular}{l}
\hline Abstrak \\
\hline Penelitian ini membahas awal waktu salat Zuhur. Perlunya \\
verifikasi fenomena siklus posisi Matahari terhadap bumi \\
dengan kriteria awal waktu salat yang berbasis hisab. Peneliti \\
membatasi pada awal waktu Zuhur karena hasil hisab Zuhur \\
menjadi kunci untuk hisab waktu salat lainnya. Penelitian ini \\
adalah penelitian lapangan dengan metode observasi. Mengacu \\
pada hasil observasi, bahwa ihtiyath waktu Zuhur berkisar 1 \\
sampai 4 menit jam antara hasil hisab dengan azan di tempat \\
observasi. Bahwa hisab awal waktu Zuhur sudah sesuai dengan \\
kaidah waktu Zuhur dimulai sejak Matahari zawal, ditandai \\
dengan hasil observasi berupa bertambah panjangnya bayangan \\
setelah kulminasi yang dibentuk oleh tongkat istiwak.
\end{tabular}

Artikel Info

Received:

01 April 2020

Revised:

21April 2020

Accepted:

18 Mei 2020

Published:

02 Juni 2020

Kata Kunci : Hisab, Observasi, Zuhur, Ihtiyath. 


\section{AL-MARSHAD: JURNAL ASTRONOMI ISLAM DAN ILMU-ILMU BERKAITAN ISSN 2442-5729 (print) || ISSN 2598-2559 (online) \\ http://jurnal.umsu.ac.id/index.php/almarshad \\ DOI: 10.30596/jam.v\% vi\%i.4462 || Vol. 6, No. 1 Juni 2020}

\section{A. Pendahuluan}

Kajian ilmu falak tidak terlepas dari hisab dan rukyat. Problematika hisab rukyat di Indonesia biasanya adalah mengenai awal bulan kamariah. Namun, dalam kaitannya dengan kajian ilmu falak dalam aspek ibadah berupa salat, hisab dan rukyat juga turut memiliki andil di dalamnya. Sejauh ini, penentuan awal waktu salat tidak memunculkan perdebatan, lain halnya dengan penentuan awal bulan kamariah, karena penentuan waktu salat dapat diatasi cukup dengan hisab. Padahal, hisab adalah sebagai data yang harus diverifikasi yaitu dengan observasi atau rukyat. Ahmad Izzuddin menyatakan bahwa hisab adalah hipotes is sedangkan rukyat adalah verifikatif.

Hisab awal waktu salat sangat berkaitan dengan waktu salat Zuhur karena pokok dari penentuan awal waktu salat yang empat selain Zuhur adalah berdasarkan penambahan hasil perhitungan sudut waktu yang dikonversi menjadi jam dengan awal waktu salat Zuhur. Pada saat zawal ditetapkan sebagai awal waktu Zuhur menurut waktu pertengahan sekaligus dijadikan sebagai pangkal hitungan untuk menentukan waktu-waktu salat lainnya. ${ }^{1}$ Firman Allah pada surah an-

${ }^{1}$ Muhyiddin Khazin, Ilmu Falak, Cet.1;
Nisa; 103 menunjukkan bahwa telah menjadi suatu kewajiban bagi umat Islam untuk berusaha mengetahui dengan benar waktu-waktu ibadah yang telah disyari'atkan. Maka, seiring kemajuan teknologi, manusia dalam hal ini dimudahkan baik dalam persoalan muamalah maupun ibadah. ${ }^{2}$

Salat merupakan ibadah yang telah ditentukan waktu dan caranya, maka umat muslim tidak boleh sembarangan dalam pelaksanaannya. Di zaman modern ini, kita akan mudah mengetahui waktu salat karena sudah adanya jadwal waktu salat sebagai acuan dalam pelaksanaan salat. Namun, kita juga perlu mengetahui awal waktu salat berdasarkan fenomena alam yang terjadi, yaitu posisi Matahari, supaya pengetahuan kita lebih komprehensif. Dengan menguji akurasi hisab dengan rukyah akan meningkatkan taraf keyakinan kita menjadi yakin, tidak sebatas zann apalagi sampai menjadikan kita ragu-ragu, syak maupun wahm.

\section{B. Me tode Penelitian}

Penelitian ini termasuk penelitian lapangan (field research). Di mana penelitian dimaksudkan untuk mengetahui sejauh mana tingkat akurasi awal waktu Zuhur yang ada di lokasi

(Yogyakarta: Buana Pustaka, 2004), h. 88.

2 Alimuddin, Perspektif Syar'i dan Sains Awal Waktu Shalat, Al-Daulah, Vol. 1, No. 1, Desember 2012, h. 121. 


\section{AL-MARSHAD: JURNAL ASTRONOMI ISLAM DAN ILMU-ILMU BERKAITAN ISSN 2442-5729 (print) || ISSN 2598-2559 (online) \\ http://jurnal.umsu.ac.id/index.php/almarshad \\ DOI: $10.30596 /$ jam.v\% vi\%i.4462 || Vol. 6, No. 1 Juni 2020}

pengamatan peneliti berdasarkan pada data hisab dan observasi yang peneliti lakukan. Penelitian ini dilakukan dengan analisis data kualitatif. Untuk bisa meneliti akurasi waktu Zuhur Masjid di tempat pengamatan, peneliti menggunakan alat berupa gnomon dari istiwa'aini untuk mengetahui panjang bayangan pada saat zawal dan menggunakan perhitungan trigonometri untuk mencocokkan panjang bayangan tersebut dengan jam. Adapun metode pengumpulan datanya adalah dengan observasi dan dokumentasi. Masjid yang peneliti jadikan tolak ukur pengamatan adalah Masjid Nurut Taqwa Perumahan Pandana Merdeka, Ngaliyan, Semarang. Peneliti memilih Masjid Nurut Taqwa sebagai tolak ukur penelitian, karena masjid ini telah menggunakan jam digital yang secara hisab, waktu Zuhurnya sesuai dengan hasil hisab waktu Zuhur yang menggunakan koreksi daerah tanpa menambahkan ihtiyath.

\section{Hasil dan Pembahasan}

\section{Awal Waktu Zuhur}

Abu Bakar Muhammad alHishny mengatakan dalam kitab Kifaayat al-Akhyaar fii Halli Ghaayat al-Ikhtishaar bahwa:

$$
\text { شيء منله بعد ظل الزو ال وقتها زوال الثمس واخره اذا صار ظل كل }
$$

"Permulaan waktu Zuhur adalah sejak tergelincirnya Matahari, dan akhir waktu
Zuhur adalah jika bayang-bayang suatu benda telah sepadan dengan benda itu selain bayang-bayang yang telah ada sejak Matahari terge linc ir" 3

Di dalam syarah kitab 'Umdah al-Saalik wa 'Uddah al-Naasik karya Syihabbudin Abi al-'Abbas Ahmad bin Lu'lu' bin Abdillah al-Rumi di dalam bab al-Mawaqit dijelaskan bahwa awal waktu Zuhur adalah ketika tergelincirnya Matahari. $^{4}$

$$
\begin{aligned}
& \text { الظهر : و اول وقتها اذا زالت الثمس و اخره مصيره } \\
& \text { ظل كل شيئ منله سوى ظل الزو ال } \\
& \text { Yang dimaksud dengan }
\end{aligned}
$$

tergelincirnya Matahari adalah apa yang tampak oleh kita, bukan yang secara kenyataan. $^{5}$ Karena yang terjadi di banyak negara, ketika Matahari kulminasi atas maka kita masih bisa mendapati bayangan. Adapun panjang bayangannya tergantung dari koordinat tempat dan pembagian musim. Jika Matahari tergelincir ke arah barat, maka akan timbul bayang-bayang baru di sebelah timur. ${ }^{6}$ Munculnya bayangan

\footnotetext{
${ }^{3}$ Abu Bakr bin Muhammad bin Abdul Mu'min al-Hishny al-Syafi'I, Kifaayat alAkhyaar fii Halli Ghayaat al-lkhtishaar, (Damaskus: Dar al-Khair, 1994).

${ }^{4}$ Syihabuddin Abi Abbas Ahmad bin Lu'lu bin Abdillah al-Rumi, 'Umdah al-Saalik wa 'Iddah al-Naasik, (Qatar: Syu'un alDiniyyah, 1982).

5 Muhammad Nawawi bin Umar alBantani al-Syafi'i, Kaasyifah al-Sajaa, (Dar Kutub al-Is lamiyah, tt.), h. 62.

Muhammad Abu Abdillah Syamsuddin Ibnu Qasim, Fath al-Qariib alMujiib, (Beirut: Dar Ibn Hazm, 2005), h. 11.
} 


\section{AL-MARSHAD: JURNAL ASTRONOMI ISLAM DAN ILMU-ILMU BERKAITAN ISSN 2442-5729 (print) || ISSN 2598-2559 (online) \\ http://jurnal.umsu.ac.id/index.php/almarshad \\ DOI: $10.30596 /$ jam.v\% vi\%i.4462 || Vol. 6, No. 1 Juni 2020}

adalah sebagai tanda awal waktu salat bagi negara yang pada saat kulminasi tidak memiliki bayangan. Adapun bagi negara yang pada saat kulminasi masih ada bayangan, maka tanda awal waktu salat Zuhur adalah bertambahnya panjang bayangan setelah bayangan terpendek. Dalam hal ini ulama sependapat bahwa awal waktu Zuhur adalah saat tergelincirnya Matahari. ${ }^{7}$

Salat merupakan salah satu rukun Is lam. Kedudukan salat sebagai ibadah wajib terdapat dalam nash (AlQuran dan Hadis). Al-Quran menyebutkan bahwa salat adalah suatu kewajiban yang pelaksanaannya dibagi kedalam beberapa waktu yang telah ditentukan. Hal ini juga menunjukkan bahwa di antara implikasi perhatian pada perintah mendirikan salat adalah perhatian terhadap seluruh syarat-syarat sah salat yang termasuk di dalamnya adalah "telah masuk waktu salat".

Berusaha mengetahui dengan benar waktu-waktu salat yang disyari'atkan adalah suatu kewajiban bagi umat Islam, baik awal maupun akhir waktu. Dengan kata lain, umat Islam wajib mengetahui waktu-waktu salat sebagaimana wajibnya mengetahui syarat-syarat sah salat yang lain seperti

Tamhid Amri, Waktu Shalat Perspektif Syar'i, Asy-Syari 'ah, Vol. 16, No. 3, Desember 2014, h. 211. bersuci, menutup aurat dan menghadap

kiblat.

Ketentuan waktu-waktu salat berkaitan dengan posisi Matahari pada bola langit. Bayangan Matahari menjadi salah satu tanda masuknya waktu salat, khususnya waktu Zuhur dan Asar. Dalam perspektif astronomi, terdapat beberapa hal penting yang harus dipahami untuk penentuan awal waktu salat Zuhur, di antaranya adalah posisi Matahari yaitu pada saat Matahari melintasi meridian / kulminasi. Pada saat inilah, bayang-bayang benda atau tongkat istiwa menjadi tanda bagi dimulainya awal pelaksanaan kewajiban ibadah seorang hamba kepada Tuhannya.

Diriwayatkan oleh Imam Malik dalam al-Muwaththa' dan Ibn Hazm dalam al-Muhalla, dari Umar, "Salatlah Zuhur apabila bayangan sepanjang satu hasta, atau bayangan manusia sepanjang satu dzira”. Jika diukur berdasarkan tinggi standar manusia pada masa itu, berarti bayangan ini $1 / 3$ tinggi manusia. Sedangkan dalam sepucuk surat Umar yang diberikan kepada Abu Musa al-Asy'ari, bahwa "Salatlah Zuhur apabila Matahari telah tergelincir dari tengah langit", 8

\footnotetext{
8 Muhammad Abdul Aziz al-Halawi, Fatwa dan Ijtihad Umar Bin Khaththab:
} 


\section{AL-MARSHAD: JURNAL ASTRONOMI ISLAM DAN ILMU-ILMU BERKAITAN ISSN 2442-5729 (print) || ISSN 2598-2559 (online) \\ http://jurnal.umsu.ac.id/index.php/almarshad \\ DOI: $10.30596 /$ jam.v\% vi\%i.4462 || Vol. 6, No. 1 Juni 2020}

Pendapat ini mengisyaratkan bahwa

salat Zuhur dimulai pada saat tergelincirnya Matahari. Pada saat

Matahari tergelincir, ada kemungkinan arah bayangan benda yang berdiri tegak:

1. Arah bayangan benda di Utara benda tersebut. Kondisi ini terjadi ketika Matahari zawal, posisi berada di belahan langit selatan, azimuth $180^{\circ}$.

2. Arah bayangan benda di selatan benda, terjadi ketika zawal posisi berada di belahan langit utara, azimuth $0^{\circ}$ sampai $360^{\circ}$.

3. Tidak ada bayangan sama sekali. Ketika zawal, posisi Matahari berada pada sudut $90^{\circ}$ diukur dari ufuk. ${ }^{9}$

\section{Ihtiyath Waktu Zuhur}

Perhitungan awal waktu salat erat hubungannya dengan ihtiyath. M. Muslih mendefinisikan ihtiyath adalah angka pengaman yang dita mbahkan pada hasil hisab waktu salat dengan tujuan seluruh penduduk suatu kota, baik yang tinggal di ujung Timur dan Barat kota dalam mengerjakan salat sudah benarbenar masuk waktu.

Kementerian Agama RI menyatakan ihtiyath adalah suatu langkah pengamanan dalam menentukan waktu salat dengan cara menambahkan atau mengurangkan waktu agar tidak

Ensiklopedia Berbagai Persoalan Fiqh, (Surabaya: Risalah Gusti, 1999), h. 53.

9 Ahmad Musonnif, Ilmu Falak, (Yogyakarta: Teras, 2011), h. 62. mendahului awal waktu salat dan tidak mela mpaui akhir waktu salat. ${ }^{10}$

Encup Supriatna mendefinisikan ihtiyath sebagai suatu langkah pengaman dengan menambah (untuk waktu Zuhur, Asar, Magrib, Isya, dan Subuh) atau mengurangkan (untuk terbit) waktu agar jadwal salat tidak mendahului atau melampaui akhir waktu. ${ }^{11}$ Dalam fikih, ihtiyath didefinisikan sebagai:

ان الاحتياط وظيفة شر عية تحول دون مخالفة تكالف

$$
\text { الثنارع }
$$

'Ihtiyath adalah ketentuan syar' iyah yang diberlakukan tanpa bertolak belakang dengan beban-beban syari' dan segala perintah-Nya".
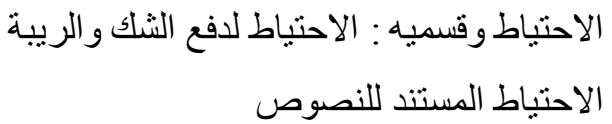

"Ihtiyath ada dua macam, ihtiyath yang menolak keraguan dan ihtiyath yang berdasarkan nash".

Ihtiyath dalam ilmu falak diketahui sebagai pemasti masuknya awal waktu salat dengan menambah sekitar dua menit. Pada buku pedoman penentuan jadwal waktu salat sepanjang masa terbitan Depag tertulis ihtiyath merupakan langkah pengamanan dengan cara menambah atau mengurangkan

10 Departemen Agama RI, Pedoman Penentuan Awal Waktu Salat Sepanjang Masa, (Jakarta: Direktorat Bimas Islam, 1986), h. 3839.

${ }^{11}$ Encup Supriatna, Hisab Rukyat dan Aplikasinya, Cet.1; (Bandung: Refika Aditama, 2007), h. vix. 
AL-MARSHAD: JURNAL ASTRONOMI ISLAM DAN ILMU-ILMU BERKAITAN ISSN 2442-5729 (print) || ISSN 2598-2559 (online)

http://jurnal.umsu.ac.id/index.php/almarshad

DOI: 10.30596/jam.v\% vi\%i.4462 || Vol. 6, No. 1 Juni 2020

waktu agar waktu salat tidak mendahului setiap waktu salat, kecuali Zuhur 4

awal atau melampaui akhir waktu. menit.

Langkah pengamanan yang dilakukan di antaranya:

1. Pembulatan nilai satuan detik, yaitu dengan dibulatkan ke satuan menit jam.

2. Jadwal waktu salat yang diberlakukan bertahun-tahun, dalam pembuatannya mengambil data yang dipergunakan dari tahun ke tahun secara rata-rata.

3. Penentuan nilai koordinat tempat, yaitu lintang dan bujur tempat diambil koordinat pusat kota. Demikian ini sebagai antisipasi bagi waktu salat daerah-daerah bagian ujung timur atau ujung barat dari suatu kota.

4. Almanak Menara kudus selalu menetapkan waktu Zuhur adalah jam 12.04 yaitu dengan mengasumsikan kulminasi Matahari pukul 12.00. Nilai ihtiyath yang digunakan adalah 4 menit. $^{12}$

5. Noor Ahmad SS menggunakan ihtiyath 3 menit untuk setiap hisab waktu salat, kecuali Zuhur dengan ihtiyath 4 menit.

6. Ibnoe Zahid Abdo el-Moeid menggunakan ihtiyath 2 menit untuk

\footnotetext{
${ }^{12}$ Mustamar Iqbal Siregar, Reevaluas Kriteria Perhitungan Awal Waktu Salat di Indonesia, At-Tafkir, Vol. 10, No. 1, Juni 2017, h. 52 .
}

7. Muhyidin Khazin menggunakan ihtiyath waktu salat adalah 1 sampai 2 menit.

Direktorat Pembinaan Badan Peradilan Agama Islam menggunakan nilai ihtiyath sekitar 2 menit, kecuali jika jadwal dimaksudkan tersebut digunakan oleh daerah sekitarnya yang jaraknya lebih dari $30 \mathrm{~km}$. Nilai ihtiyath 1-2 menit dianggap cukup sebagai kehatihatian terhadap pembulatan-pembulatan dan data rata-rata, nilai itu menjangkau 27,5 sampai $55 \mathrm{~km}$ ke arah barat atau timur. $^{13}$

Secara teoritik selisih $1^{\circ}$ bujur sama dengan $111 \mathrm{~km}$ dan perbedaannya 4 menit dalam ukuran waktu. Penggunaan ihtiyath 1 menit sama dengan 111: 4 = jarak 27,75 km (dalam arah Barat - Timur). Ihtiyath sebenarnya tidak hanya berkaitan dengan bujur saja, namun juga dengan ketinggian tempat. Bagi perhitungan awal waktu salat yang memperhitungkan kerendahan ufuk, maka koreksian ketinggian tempat, semidiameter, dan refraksi sangatlah diperlukan. Hal ini dimaksudkan karena kondisi suatu kota atau daerah adakalanya memiliki bagian yang tinggi dan yang rendah. Daerah yang tinggi h. 37-39.

${ }^{13}$ Departemen Agama RI, Pedoman ..., Copyright C2020. Al-Marshad: JurnalAstronomi Islam danIlmu-IlmuBerkaitan. This is an open acces article under the CC-BY-SA lis ence (https://creativecommons .org/licens es/by-sa/4.0/). 
AL-MARSHAD: JURNAL ASTRONOMI ISLAM DAN ILMU-ILMU BERKAITAN ISSN 2442-5729 (print) || ISSN 2598-2559 (online)

http://jurnal.umsu.ac.id/index.php/almarshad

DOI: $10.30596 /$ jam.v\% vi\% i.4462 || Vol. 6, No. 1 Juni 2020

akan berimplikasi pada terbenamnya kontroversi. ${ }^{14}$ Dari hadis Jabir bin

Matahari yang lebih lambat dari pada daerah yang rendah.

Untuk melihat akurasi perhitungan dengan menggunakan koreksian daerah, berikut analisisnya:

a. Koreksi daerah memperhitungkan perbedaan bujur daerah. Perbedaan $1^{\circ}$ bujur biasanya dikonversi sama dengan 4 menit. Daerah yang berada di sebelah Barat kota yang dijadikan titik hisab jadwal salat, koreksiannya ditambahkan. Sedangkan daerah yang berada di sebelah Timurnya, maka dikurangkan.

b. Perhitungan awal waktu salat berkaitan erat dengan posisi harian Matahari. Sedangkan perhitungan awal waktu salat juga menggunakan data lintang tempat untuk mengetahui posisi Matahari, karena koordinat lintang berhubungan dengan deklinasi Matahari. Koordinat lintang suatu daerah sangat terkait dengan posisi Matahari dalam peredaran tahunannya di ekliptika. Maka, tidak hanya koreksi bujur saja melainkan juga koreksi lintang dibutuhkan dalam hisab waktu salat.

\section{His ab Waktu Zuhur}

Di antara lima waktu salat fardu, Zuhur termasuk salat yang penentuan awal waktunya relatif tidak menuai
Abdullah dije laskan bahwa awal waktu salat Zuhur adalah hiina zaalat al-syams atau sesaat setelah Matahari mencapai titik kulminasi atas. Fenomena ini dinilai relevan dengan kriteria hisab awal waktu salat Zuhur menggunakan rumus: ${ }^{15}$

$12-\mathrm{e}^{16}+\left(\lambda^{\mathrm{d}}-\lambda^{\mathrm{x}}\right) / 15$

$\lambda^{\mathrm{d}}=$ Bujur daerah

$\lambda^{\mathrm{x}} \quad=$ Bujur tempat

Awal waktu Zuhur didefinisikan sejak seluruh bundaran Matahari meninggalkan meridian, atau sekitar 2 menit setelah tengah hari. Matahari tergelincir yang dipahami sebagai awal waktu Zuhur adalah posisi Matahari setelah bergeser dari kulminasinya (bergeser dari meridian). Kedudukan Matahari dalam poin ini adalah posisi titik pusat Matahari. Saat berkulminasi atas, pusat Matahari berada di meridian, maka saat zawal adalah ketika titik pusat Matahari lepas dari meridian setempat. Apabila Matahari bergeser dari meridian atau ketika bergeser dari titik zenith, maka titik pusatnya juga bergeser.

${ }^{14}$ Muhammad Jawad Mughniyah, Fikih Lima Mazhab, Jilid IV, Terj. Masykur A.B dkk, dari Al-Fiqh 'Ala al-Madzahib al-Khamsah, (Jakarta: Lentera, 2001), h. 73-74.

15 Slamet Hambali, Ilmu Falak 1 (Penentuan Awal Waktu Shalat dan Arah Kiblat Seluruh Dunia), (Semarang: Program Pas casarjana IAIN Walisongo, 2011), h. 144.

${ }^{16}$ Selisih waktu antara waktu Matahari hakiki dengan waktu Matahari rata-rata. Lihat Muhyiddin Khazin, Kamus Ilmu Falak, (Yogyakarta: Buana Pustaka, 2005), h. 79. 


\section{AL-MARSHAD: JURNAL ASTRONOMI ISLAM DAN ILMU-ILMU BERKAITAN ISSN 2442-5729 (print) || ISSN 2598-2559 (online) \\ http://jurnal.umsu.ac.id/index.php/almarshad \\ DOI: $10.30596 /$ jam.v\%vi\%i.4462 || Vol. 6, No. 1 Juni 2020}

Lintang tempat dan deklinasi Matahari mempengaruhi bergesernya titik kulminasi Matahari.

Rumus yang digunakan saat kulminasi adalah 12 - e. Angka 12.00 dianggap sama dengan $90^{\circ}$ karena Matahari berada pada titik zenith. Rumus ini adalah turunan dari $\mathrm{Zm}=(\mathrm{p}$ d), karena tinggi Matahari $90^{\circ}$, maka $\mathrm{p}=$ d juga. Dengan demikian $\mathrm{hm}=90^{\circ}-(\mathrm{p}-$ d), karena $\mathrm{Zm}$, p, dan d harganya dianggap sama dengan 0. Dari proses inilah, awal waktu salat Zuhur yang dipahami "tergelinc ir Matahari”. ${ }^{17}$

Saat Matahari berkulminasi, berarti saat Matahari berada di meridian pass. Jika MerPass lebih dari jam 12.00 berarti perata waktu bertanda negatif (-), dan jika MerPass kurang dari jam 12.00 berarti perata waktu bertandapositif (+). Data perata waktu atau yang disebut dengan equation of time ini setiap hari akan berganti, namun dari tahun ke tahun relatif sama.

The nautical almanac dan American ephemeris selalu memuat saat Matahari berkulminasi dalam data harian. The American ephemeris mencantumkan saat Matahari berkulminasi dengan istilah ephemeris transit. Datanya disediakan dalam satuan jam, menit dan detik hingga 2 angka di

17 Ali Parman, Ilmu Falak, (Ujung Pandang: Yayasan Al-Ahkam, 2001), h. 26. belakang koma. Almanak nautika mengistilahkan Matahari berkulminasi sebagai MerPass dengan satuan jam dan menit. Data equation of time untuk jam 00 dan jam 12.00 GMT juga disediakan dalam satuan menit dan detik. ${ }^{18}$

Cara menentukan waktu salat secara tekstual bisa dilakukan dengan melihat langsung tanda-tanda alam seperti menggunakan a lat bantu tongkat istiwak atau miqyas atau hemispherium. Metode inilah yang digunakan oleh mazhab rukyah dalam persoalan penentuan waktu salat. ${ }^{19}$ Adapun secara kontekstual, awal dan akhir waktu salat ditentukan berdasarkan posisi Matahari dilihat dari suatu tempat di bumi, sehingga metode yang digunakan adalah dengan hisab, karena pada hakikatnya waktu salat adalah menghitung atau mengetahui kapan Matahari akan menempati posisi-posisi yang sesuai dengan nash-nash waktu salat.

Pada saat titik pusat Matahari melakukan perjalanan ke arah Barat bersamaan melepaskan diri dari meridian maka ujung bayangan benda yang berdiri tegak lurus akan melepaskan diri dari garis utara-selatan dan menuju arah timur. Posisi inilah yang dikenal dengan tergelincirnya Matahari sebagai awal

${ }^{18}$ Susiknan Azhari, Awal Waktu Shalat Perspektif Syar'i dan Sains, (Yogyakarta: Suara Muhammadiyah, 2004), h. 73.

${ }^{19}$ www.alhus iniyah.com. 
AL-MARSHAD: JURNAL ASTRONOMI ISLAM DAN ILMU-ILMU BERKAITAN ISSN 2442-5729 (print) || ISSN 2598-2559 (online)

http://jurnal.umsu.ac.id/index.php/almarshad

DOI: 10.30596/jam.v\% vi\% i.4462 || Vol. 6, No. 1 Juni 2020

waktu Zuhur.

Menurut Abdurrachim, secara ilmu pasti waktu berkulminasi Matahari dapat ditetapkan sebagai batas permulaan waktu Zuhur. $^{20}$ Dalam penentuan jadwal salat, data astronomi terpenting adalah posisi Matahari dalam koordinat horizon, terutama ketinggian atau jarak zenith. Astronomi memiliki peran menafsirkan fenomena yang disebutkan dalam alquran dan hadis Nabi menjadi posisi Matahari. ${ }^{21}$

Data yang diperlukan untuk menghitung awal waktu salat Zuhur adalah sebagai berikut :

\section{MeridianPass (MP)}

Merpass (meridian pass) adalah ketika arah bayangan suatu benda yang tegak tepat ke utara dan selatan. Kulminasi Matahari dapat diperoleh dengan cara mengurangi waktu hakiki dengan perata waktu (equation of time yang disimbolkan dengan e). Merpass $=$ $12-\mathrm{e})$.

2. Koordinat Lintang Tempat $(\Phi)$.

Lintang adalah garis vertikal yang mengukur sudut antara suatu titik dengan garis khatulistiwa. Daerah yang terletak di sebelah utara garis khatulistiwa memiliki lintang bernilai positif, dan daerah yang terletak di

\footnotetext{
${ }^{20}$ Abdur Rachim, Ilmu Falak, Cet. I., (Yogyakarta: Liberty, 1983), h. 23.

${ }^{21} \mathrm{http}: / / \mathrm{t}$-djamaluddin.spaces .live.com.
}

sebelah selatan garis khatulistiwa memiliki lintang bernilai negatif. ${ }^{22}$ Perbedaan lintang tidak sama besar pengaruhnya terhadap waktu salat sepanjang tahun.

3. Koordinat Bujur Tempat $(\lambda)$.

Bujur astronomi suatu tempat adalah horizontal yang mengukur sudut antara suatu titik dengan titik nol di Bumi yaitu Greenwich di London Britania Raya yang merupakan titik bujur $0^{\circ}$ atau $360^{\circ}$ yang diterima secara internasional. ${ }^{23}$ Daerah yang terletak di sebelah timur Greenwich sampai $180^{\circ}$ memiliki bujur positif (BT) dan untuk daerah yang terletak di sebelah barat Greenwich sampai $180^{\circ}$ memiliki bujur negatif (BB). Nilai bujur tempat berhubungan dengan waktu, artinya untuk mendapatkan standar waktu internasional GMT, wilayah bujur barat harus dikurangi angka tertentu. Sebaliknya, bujur timur harus ditambah dengan angka tertentu. Perbedaan $1^{\circ}$ bujur berarti perbedaan 4 menit waktu, perbedaan bujur sebesar $0,1^{\circ}$ atau jarak tepat ke timur atau tepat ke barat sejauh $11 \mathrm{~km}$ berarti perbe daan waktu sebanyak 0,4 menit atau 24 detik. Jarak 27 1/2 km tepat ke barat atau ke timur berarti perbedaan waktu sebanyak satu menit.

22 Slamet Hambali, Pengantar Ilmu Falak, (Banyuwangi: Bismillah Publisher, 2012), h. 298.

\footnotetext{
${ }^{23}$ Hambali, Pengantar..., h. 299.
} 


\section{AL-MARSHAD: JURNAL ASTRONOMI ISLAM DAN ILMU-ILMU BERKAITAN ISSN 2442-5729 (print) || ISSN 2598-2559 (online) \\ http://jurnal.umsu.ac.id/index.php/almarshad \\ DOI: 10.30596/jam.v\% vi\%i.4462 || Vol. 6, No. 1 Juni 2020}

4. Koreksi Waktu Daerah (KWD)

Untuk mengubah waktu istiwak yang dihasilkan dari perhitungan awal waktu salat dengan menggunakan datadata GMT, harus dilakukan koreksi untuk mengetahui waktu setempat. Rumus koreksi waktu daerah : $\left(\lambda^{\mathrm{d}}-\lambda^{\mathrm{x}}\right) /$ 15

Waktu daerah yang disesuaikan menurut bujur daerah dengan berpedoman meridian yang melintasi kira-kira pada pertengahan daerah bersangkutan. Indonesia terbagi menjadi 3 zona: ${ }^{24}$

a. Waktu Indonesia Barat $105^{\circ}$ dengan zona waktu GMT $+7^{\mathrm{j}}$

b. Waktu Indonesia Tengah $120^{\circ}$ dengan zona waktu GMT $+8^{\mathrm{j}}$

c. Waktu Indonesia Timur $135^{\circ}$ dengan zona waktu GMT $+9^{j}$

5. Equation of Time.

Equation of time adalah selis ih antara kulminasi Matahari hakiki dengan waktu kulminasi Matahari rata-rata (jam 12:00). Dalam bahasa Indonesia dinamakan perata waktu.

6. Panjang Bayangan

Waktu Zuhur dimulai ketika tergelincirnya Matahari dari tengah meridian langit (istiwa) ke arah barat ditandai dengan munculnya bayangan suatu benda sesaat setelah Matahari di

\footnotetext{
${ }^{24}$ Abdur Rachim, Ilmu ..., h. 55-57.
}

tengah langit, atau bertambahnya

panjang bayangan suatu benda sesaat setelah Matahari berkulminasi. Posisi Matahari dalam pada saat ini adalah ketika telah melampaui titik kulminasi di titik pusatnya dan telah bergeser ke arah barat.

\section{Akurasi Awal Waktu Zuhur}

Akurasi berarti kecermatan, ketelitian, dan ketepatan. ${ }^{25}$ Adapun akurasi dalam kaitannya dengan waktu salat adalah ketepatan azan sebagai tanda awal waktu salat Zuhur dengan hasil pengamatan yang peneliti lakukan dengan menggunakan alat berupa gnomon dari istiwa'aini. Pengamatan tersebut disesuaikan dengan hisab waktu Zuhur yang telah peneliti persiapkan.

Dalam perhitungan awal waktu salat ada beberapa hal yang menjadi perhatian sehingga biasanya jadwal waktu sa lat cukup dengan pembulatan di menitnya:

a. Hisab awal waktu salat yang biasa dilakukan yaitu dengan menggunakan data deklinasi Matahari dan equation of time pada hari perhitungan awal waktu Zuhur, karena data deklinasi Matahari dalam satu hari tidak banyak perubahannya.

${ }^{25}$ H. E. Rais, Kamus Ilmiah Populer: Memuat Berbagai Kata dan Istilah Dalam Bidang Politik, Sosial, Budaya, Sains dan Teknologi, Psikologi, Kedokteran, Pendidikan, (Yogyakarta: Pus taka Pelajar, 2012). 
AL-MARSHAD: JURNAL ASTRONOMI ISLAM DAN ILMU-ILMU BERKAITAN ISSN 2442-5729 (print) || ISSN 2598-2559 (online)

http://jurnal.umsu.ac.id/index.php/almarshad

DOI: 10.30596/jam.v\% vi\% i.4462 || Vol. 6, No. 1 Juni 2020

b. Sebuah jadwal salat hanya mencantumkan waktu dalam ukuran jam dan menit karena jika hisab yang dilakukan dengan menggunakan data-data yang riil dan dilakukan koreksi-koreksi posisi Matahari dengan akurasi tinggi menghasilkan perbedaan hasil hisab hanya pada satuan detik jam. Perubahan ini tidak signifikan karena yang dibutuhkan dalam hasil hisab awal waktu salat sampai dengan hitungan menit saja.

Walaupun demikian, tidak menutup kemungkinan, terdapat daerah yang tidak dapat dikover dengan ihtiyath 2 menit, seperti daerah di bawah (lereng) gunung. Baik lereng timur gunung atau barat gunung, yang tentunya memiliki waktu salat tersendiri, khususnya dalam hal akhir waktu salat Subuh dan awal waktu salat Magrib.

Selain ihtiyath, koreksi daerah menjadi salah satu alternatif penggunaan jadwal waktu salat. Koreksi daerah adalah koreksi waktu berupa penambahan atau pengurangan menit untuk penyesuaian jikalau suatu jadwal salat digunakan di daerah atau kota lain, biasanya disebut dengan tafawut. Penggunaan koreksi daerah menjadi suatu diskusi panjang di kalangan ahli Falak. Dengan melihat pada adanya fenomena suatu tempat dalam satu daerah lain di luar peruntukan jadwal Copyright C2020. Al-Marshad: JumalAstronomi Islam danIlmu-IlmuBerkaitan. This is an open acces article under the CC-BY-SA lis ence (https://creativecommons .org/licens es/by-sa/4.0/). yang belum tentu bisa dikover dengan nilai tafawut yang disediakan, karena sesungguhnya yang baik adalah satu jadwal untuk satu kota atau kabupaten, sebagaimana pernah disampaikan oleh Slamet Hambali dalam lokakarya imsakiyah di UIN Walisongo Semarang.

Penelitian ini menggunakan alat berupa gnomon istiwa'aini. Istiwa'aini merupakan alat berbentuk lingkaran dengan bidang dial yang memiliki gnomon atau tongkat untuk menangkap bayangan Matahari yang selanjutnya diketahui panjang bayangan pada waktu Zuhur, atau sebaliknya dari panjang bayangan tersebut bisa digunakan untuk menentukan jam. Adapun jam yang peneliti gunakan adalah jam yang sudah disesuaikan dengan jam bmkg.

Data yang digunakan untuk hisab waktu Zuhur adalah koordinat tempat dengan Lintang $07^{\circ} 00^{\prime} 33.81$ " LS dan $110^{\circ} 20$ '09.76" BT. Adapun Masjid Nurut Taqwa berada di koordinat $7^{\circ} 00^{\prime}$ 14 " LS dan $110^{\circ} 20^{\prime} 14$ " BT. Sedangkan data deklinasi dan equation of time diambil dari data Ephemeris Hisab Rukyat Kemenag RI tahun 2018. 


\section{AL-MARSHAD: JURNAL ASTRONOMI ISLAM DAN ILMU-ILMU BERKAITAN ISSN 2442-5729 (print) || ISSN 2598-2559 (online) \\ http://jurnal.umsu.ac.id/index.php/almarshad \\ DOI: $10.30596 /$ jam.v\% vi\% i.4462 || Vol. 6, No. 1 Juni 2020}

Tabel 1. Data Deklinasi dan Equation of Time $^{26}$

\begin{tabular}{|c|c|c|}
\hline Tanggal & Declination & $\begin{array}{c}\text { Equation } \\
\text { of time }\end{array}$ \\
\hline $\begin{array}{c}\text { Rabu, 24-10- } \\
2018\end{array}$ & $-11^{\mathrm{o}} 43^{\prime} 34^{\prime \prime}$ & $0^{\mathrm{j}} 15^{\mathrm{m}} 48^{\mathrm{d}}$ \\
\hline $\begin{array}{c}\text { Sabtu, 10-11- } \\
2018\end{array}$ & $-17^{\mathrm{o}} 07^{\prime} 06^{\prime \prime}$ & $0^{\mathrm{j}} 16^{\mathrm{m}} 09^{\mathrm{d}}$ \\
\hline $\begin{array}{c}\text { Ahad, 11-11- } \\
2018\end{array}$ & $-17^{\mathrm{o}} 23^{\prime} 50^{\prime \prime}$ & $0^{\mathrm{j}} 16^{\mathrm{m}} 03^{\mathrm{d}}$ \\
\hline $\begin{array}{c}\text { Selasa, 13-11- } \\
2018\end{array}$ & $-17^{\mathrm{o}} 56^{\prime} 23^{\prime \prime}$ & $0^{\mathrm{j}} 15^{\mathrm{m}} 48^{\mathrm{d}}$ \\
\hline $\begin{array}{c}\text { Rabu, 14-11- } \\
2018\end{array}$ & $-18^{\mathrm{o}} 12^{\prime} 12^{\prime \prime}$ & $0^{\mathrm{j}} 15^{\mathrm{m}} 39^{\mathrm{d}}$ \\
\hline $\begin{array}{c}\text { Kamis, 15-11- } \\
2018\end{array}$ & $-18^{\mathrm{o}} 27^{\prime} 42^{\prime \prime}$ & $0^{\mathrm{j}} 15^{\mathrm{m}} 30^{\mathrm{d}}$ \\
\hline $\begin{array}{c}\text { Sabtu, 17-11- } \\
2018\end{array}$ & $-18^{\mathrm{o}} 57^{\prime} 42^{\prime \prime}$ & $0^{\mathrm{j}} 15^{\mathrm{m}} 08^{\mathrm{d}}$ \\
\hline $\begin{array}{c}\text { Senin, 26-11- } \\
2018\end{array}$ & $-20^{\mathrm{o}} 55^{\prime} 14^{\prime \prime}$ & $0^{\mathrm{j} 1} 12^{\mathrm{m}} 49^{\mathrm{d}}$ \\
\hline $\begin{array}{c}\text { Rabu, 28-11- } \\
2018\end{array}$ & $-21^{\mathrm{o}} 17^{\prime} 12^{\prime \prime}$ & $0^{\mathrm{j}} 12^{\mathrm{m}} 10^{\mathrm{d}}$ \\
\hline
\end{tabular}

Data di atas adalah nilai deklinasi Matahari dan equation of time yang peneliti gunakan selama melakukan observasi awal waktu Zuhur. Data-data itu diperoleh dari aplikasi winhisab Kemenag RI, atau bisa dilihat di buku Ephemeris Hisab Rukyat Kemenag RI yang terbit setiap tahun. Deklinasi dan equation of time diambil untuk data jam 5 GMT, karena selisih waktu WIB (tempat observasi) dengan GMT adalah

${ }^{26}$ Kementerian Agama RI, Ephemeris Hisab Rukyat 2018, (Jakarta: Direktorat Urusan Agama Is lam dan Pembinaan Syariah Bimas Islam, 2017).
7 jam. Data yang dibutuhkan adalah data untuk jam 12 WIB, artinya sama dengan jam 5 GMT.

Hisab waktu Zuhur berikut ini penulis dapatkan de ngan rumus:

1. Meridian pass

Merpass $=12-\mathrm{e}$

2. Koreksi Waku Daerah

KWD $=$ (Bujur Daerah - Bujur

Tempat) : 15

3. Awal Waktu Zuhur

Zuhur $=12-\mathrm{e}+\mathrm{KWD}$

4. Panjang Bayangan

Waktu Hakiki $=$ Jam Bidik $-\mathrm{e}+(\mathrm{BD}-\mathrm{BT})$ $: 15$

Sudut Waktu $=(\mathrm{WH}-12) \times 15$

$\operatorname{Sin} \mathrm{h}$ Matahari $=\mathrm{Sin}$ LT $\mathrm{x} \sin \mathrm{d}+\cos \mathrm{LT} \mathrm{x}$ $\cos d x \cos t$

$\mathrm{PB}=$ panjang tongkat $/ \tan \mathrm{h}$

\section{LT : lintang tempat}

d : deklinasi Matahari

e : perata waktu

t : sudut waktu Matahari

h : tinggi Matahari

Gambar 1. Koordinat Masjid Nurut Taqwa, Ngaliyan

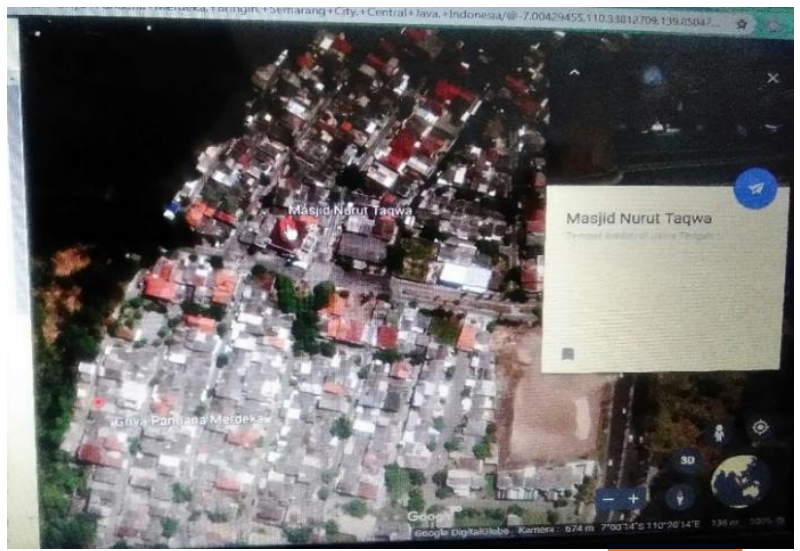


AL-MARSHAD: JURNAL ASTRONOMI ISLAM DAN ILMU-ILMU BERKAITAN

ISSN 2442-5729 (print) || ISSN 2598-2559 (online)

http://jurnal.umsu.ac.id/index.php/almarshad

DOI: $10.30596 /$ jam.v\% vi\% i.4462 || Vol. 6, No. 1 Juni 2020

Tabel 3. Panjang Bayangan Saat

Koordinat lintang dan bujur

Kulminasi dan Zawal

Masjid Nurut Taqwa, Ngaliyan,

Semarang diambil dari google earth.

Tabel 2. Selisih Hasil Hisab Waktu Zuhur dengan Waktu Azan Zuhur Masjid Nurut Taqwa, Ngaliyan

\begin{tabular}{|c|c|}
\hline Azan & Selisih \\
\hline $11: 24: 37$ & $00^{\mathrm{J}} 01^{\mathrm{m}} 43^{\mathrm{d}}$ \\
\hline $11: 24: 41$ & $00^{\mathrm{J}} 02^{\mathrm{m}} 02^{\mathrm{d}}$ \\
\hline $11: 25: 34$ & $00^{\mathrm{J}} 02^{\mathrm{m}} 40^{\mathrm{d}}$ \\
\hline $11: 25: 34$ & $00^{\mathrm{J}} 02^{\mathrm{m}} 31^{\mathrm{a}}$ \\
\hline $11: 24: 01$ & $00^{\mathrm{J}} 00^{\mathrm{m}} 48^{\mathrm{d}}$ \\
\hline $11: 25: 16$ & $00^{\mathrm{J}} 01^{\mathrm{m}} 42^{\mathrm{d}}$ \\
\hline $11: 29: 00$ & $00^{\mathrm{J}} 03^{\mathrm{m}} 09^{\mathrm{d}}$ \\
\hline $11: 27: 58$ & $00^{\mathrm{J}} 01^{\mathrm{m}} 28^{\mathrm{d}}$ \\
\hline
\end{tabular}

Dari tabel di atas disajikan bahwa selisih antara hasil hisab waktu Zuhur dengan azan berkisar dari 1 hingga 2 menit.

Gambar 2. Panjang Bayangan Saat

Observasi Waktu Zuhur

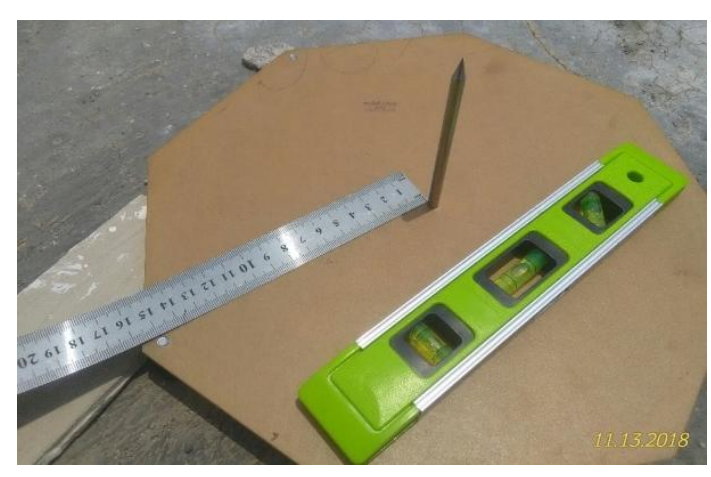

\begin{tabular}{|c|c|c|}
\hline Tanggal & Kulminasi & Zawal \\
\hline $24-10-2018$ & 0.8234463802 & 0.8234467198 \\
\hline $10-11-2018$ & 1.781466694 & 1.781467138 \\
\hline $11-11-2018$ & 1.831746331 & 1.831746767 \\
\hline $13-11-2018$ & 1.929848677 & 1.929849098 \\
\hline $14-11-2018$ & 1.977625478 & 1.97762589 \\
\hline $15-11-2018$ & 2.024522713 & 2.024523222 \\
\hline $17-11-2018$ & 2.115583805 & 2.115584194 \\
\hline $26-11-2018$ & 2.475832424 & 2.475832814 \\
\hline $28-11-2018$ & 2.54383732 & 2.543837688 \\
\hline
\end{tabular}

Tabel di atas adalah hasil hisab

panjang bayangan tongkat sepanjang 10

cm ketika kulminasi dan zawal yaitu

dengan membulatkan nilai detik pada jam hisab waktu Zuhur ke satuan menit sebagai acuan bayangan zawal. Berdasarkan data dalam tabel, bahwa panjang bayangan saat jam dan menit hisab awal waktu Zuhur tanpa ihtiyath menunjukkan panjang bayangan yang ditangkap sudah lebih panjang daripada saat kulminasi, sehingga azan yang dikumandangkan tepat pada awal waktu Zuhur tanpa ihtiyath pun telah masuk waktu, dengan catatan detik dibulatkan ke dalam satuan menit. 


\section{AL-MARSHAD: JURNAL ASTRONOMI ISLAM DAN ILMU-ILMU BERKAITAN ISSN 2442-5729 (print) || ISSN 2598-2559 (online) \\ http://jurnal.umsu.ac.id/index.php/almarshad \\ DOI: 10.30596/jam.v\% vi\%i.4462 || Vol. 6, No. 1 Juni 2020}

\section{Kesimpulan}

Berdasarkan hasil hisab dan observasi di lapangan, bahwasanya azan Zuhur dikumandangkan ketika selis ih antara hisab waktu Zuhur dengan azan tersebut lebih dari 30 detik. Hal ini menunjukkan bahwa azan Zuhur yang dikumandangkan telah sesuai dengan hisab yang digunakan. Dengan artian, salat Zuhur tidak dikerjakan di waktu yang dilarang untuk mengerjakan salat, yaitu ketika kulminasi. Ihtiyath yang digunakan mulai dari 48 detik hingga 3 menit 9 detik jam. Adapun melaksanakan salat Zuhur tepat sesuai dengan hasil hisab awal waktu Zuhur di suatu tempat tanpa penggunaan ihtiyath pun sudah dikatakan masuk awal waktu, karena panjang panjangan saat itu telah melebihi panjang saat kulminasi. Dengan catatan detik berapapun dibulatkan menjadi menit, dan hasil hisab itu digunakan di daerah yang datanya digunakan untuk hisab, sebab awal waktu Zuhur termasuk riskan karena berkaitan dengan saat kulminasi Matahari.

\section{Daftar Pustaka}

Abdur Rachim. 1983. Ilmu Falak. Yogyakarta: Liberty.

Ahmad Musonnif. 2011. Ilmu Falak. Yogyakarta: Teras.

Ali Parman. 2001. Ilmu Falak. Ujung
Pandang: Yayasan Al-Ahkam.

Alimuddin. 2012. Perspektif Syar'i dan Sains Awal Waktu Shalat. AlDaulah, 1(1), 120-131.

al-Rumi, Syihabuddin Abu Abbas Ahmad bin Lu'lu bin Abdillah. 1982. 'Umdah al-Saalik wa 'Iddah al-Naasik. Qatar: Syu'un al-Diniyyah.

al-Syafi' i, Abu Bakr bin Muhammad bin

Abdul Mu'min al-Hishny. 1994.

Kifaayat al-Akhyaar fii Halli

Ghayaat al-lkhtishaar. Damaskus:

Dar al-Khair.

al-Syafi'i, Muhammad Nawawi bin Umar al-Bantani. tt. Kaasyifah alSajaa. Dar Kutub al-Is lamiyah.

Departemen Agama RI. 1986. Pedoman

Penentuan Awal Waktu Salat Sepanjang Masa. Jakarta:

Direktorat Bimas Islam.

Encup Supriatna. Hisab Rukyat dan Aplikasinya. 2007. Bandung: Refika Aditama.

H. E. Rais. Kamus Ilmiah Populer: Meтuat Berbagai Kata dan Istilah dalam Bidang Politik, Sosial, Budaya, Sains dan Teknologi, Psikologi, Kedokteran,

Pendidikan. 2012. Cet. 1.

Yogyakarta: Pustaka Pelajar.

http://t-djamaluddin.spaces.live.com

Kementerian Agama RI. 2017.

Ephemeris Hisab Rukyat 2018, 
AL-MARSHAD: JURNAL ASTRONOMI ISLAM DAN ILMU-ILMU BERKAITAN ISSN 2442-5729 (print) || ISSN 2598-2559 (online)

http://jurnal.umsu.ac.id/index.php/almarshad

DOI: $10.30596 /$ jam.v\% vi\% i.4462 || Vol. 6, No. 1 Juni 2020

Jakarta: Direktorat Urusan Agama Tamhid Amri. 2014. Waktu Shalat

Islam dan Pembinaan Syariah Perspektif Syar'i. Asy-Syari'ah,

Bimas Islam. 16(3), 206-215.

Muhammad Abdul Aziz al-Halawi.

1999. Fatwa dan Ijtihad Umar bin

Khaththab: Ensiklopedia Berbagai

Persoalan Fiqh. Surabaya: Risalah

Gusti.

Muhammad Abu Abdillah Syamsuddin

Ibnu Qasim. 2005. Fath al-Qariib

al-Mujiib, Beirut: Dar Ibn Hazm.

Muhammad Jawad Mughniyah. 2001.

Fikih Lima Mazhab Jilid IV. Terj.

Masykur A.B dkk. dari Al-Fiqh

'Ala al-Madzahib al-Khamsah.

Jakarta: Lentera.

Muhyiddin Khazin. 2004. Ilmu Falak.

Yogyakarta: Buana Pustaka.

Mustamar Iqbal Siregar. 2017.

Reevaluasi Kriteria Perhitungan

Awal Waktu Salat di Indonesia.

At-Tafkir, 10(1), 38-63.

Slamet Hambali. 2011. Ilmu Falak 1

(Penentuan Awal Waktu Shalat dan

Arah Kiblat Seluruh Dunia).

Semarang: Program Pascasarjana

IAIN Walisongo.

Slamet Hambali. 2012. Pengantar Ilmu

Falak. Banyuwangi: $\mathrm{B}$ is millah

Publisher.

Susiknan Azhari. 2004. Awal Waktu

Shalat Perspektif Syar'i dan Sains.

Yogyakarta:

SuaraMuha mmadiyah. 